\title{
PENGARUH KEBERHASILAN DIRI, TOLERANSI AKAN RISIKO, DAN KEBEBASAN DALAM BEKERJA TERHADAP MOTIVASI BERWIRAUSAHA PADA MAHASISWA PROGRAM STUDI PENDIDIKAN EKONOMI STKIP PGRI BANGKALAN
}

\author{
Indah Purnama Sari*
}

\begin{abstract}
The aim of this research was to investigate the influence of self achievement, risk of tolerance, and freedom of work on enterpreneurships motivation. The population as same as the sample were 120 of seventh semester student at the economic education program of STIKIP PGRI Bangkalan in the academic year 2012/2013. The data were collected through questionaires. The data were then analyzed with quantitative analysis by multiple linier regressions. Based on the partial test (t test), it showed that self achievement had significant influence on enterpreneurships motivation, risk of tolerance had significant influence on enterpreneurships motivation while freedom of work had not significant influence on enterpreneurships motivation. Based on the significance test (f test), it showed simultaneously that self achievement, risk of tolerance and freedom of work had significant influence on enterpreneurships motivation.
\end{abstract}

Keywords: motivation, self achievement, risk tolerance and freedom work

\section{PENDAHULUAN}

$\mathrm{T}$ idak ada satu bangsa di dunia ini yang mampu menjadi negara maju tanpa ditopang sejumlah pemuda dan masyarakat yang berwirausaha. Di negara-negara maju baik di Benua Eropa maupun Amerika Serikat, setiap sepuluh menit lahir wirausahawan baru (Saiman, 2009: 22). Pertumbuhan wirausaha ini membawa peningkatan perekonomian yang luar biasa bagi suatu negara, sehingga semakin banyak suatu negara memiliki wirausaha, semakin meningkat perekonomiannya. Adapun Indonesia menurut data Kemenkop dan UKM (2012) pada tahun 2012 Indonesia baru memiliki 1,56 persen. Artinya, masih kurang sejumlah 0,44 persen wirausaha untuk mencapai angka ideal 2 persen. Hal ini sebagaimana pernyataan dari PBB bahwa suatu negara akan dapat dikatakan sebagai negara maju apabila memiliki wirausaha sebanyak 2 persen dari jumlah penduduknya (Alma, 2009: 4). Data ini menunjukkan perlunya upaya bersama untuk menumbuh kembangkan wirausaha.

Perguruan tinggi sangat strategis dalam perannya mengembangkan sikap mental, motivasi, dan pengetahuan kewirausahaan mahasiswa. Melalui kurikulum yang memuat mata kuliah kewirausahaan perguruan tinggi meemiliki harapan dan tujuan agar lulusannya tidak bingung dan canggung terjun ke masyarakat, mereka memiliki mental sebagai seorang wirausaha, memahami dunia wirausaha, dan motivasi yang tinggi untuk berwi-

*) Dosen STKIP PGRI Bangkalan 
rausaha sehingga tidak lagi menyalahkan perguruan tingginya yang menghasilkan lulusan menganggur. Sebagai salah satu perguruan tinggi swasta di Jawa Timur yang fokus menyelenggarakan pendidikan keguruan, sejak tahun berdirinya (1975) hingga saat ini STKIP PGRI Bangkalan senantiasa menunjukkan kepedulian terhadap permasalahan alumni menganggur. Hal ini mengingat lapangan kerja sektor pendidikan sangat terbatas. Setiap tahun melalui wisuda setidaknya STKIP PGRI Bangkalan mensupply lebih dari 500 calon tenaga guru. Tentu jumlah ini tidak sebanding dengan daya serap lapangan kerja sektor pendidikan. Timpangnya jumlah angkatan kerja dengan daya serap lapangan kerja memunculkan fenomena pengangguran terdidik bagi output STKIP PGRI Bangkalan, utamanya sebagai calon tenaga guru yang tidak terserap oleh sekolah. Oleh karena itu, salah satu upaya mengatasi masalah ini adalah dengan mewajibkan mata kuliah kewirausahaan dalam kurikulum semua Program Studi. Diharapkan setelah lulus bangku kuliah mahasiswa memiliki bekal pengetahuan yang cukup untuk membuka usaha mandiri. Terlebih jika wirausaha ini dapat diselaraskan dengan potensi dan keunggulan yang ada di wilayah Bangkalan. Dari hasil studi pendahuluan menunjukkan bahwa mahasiswa STKIP PGRI Bangkalan yang melakukan kegiatan berwirausaha sebesar $38 \%$, dari jumlah tersebut $32 \%$ masih menjalankan usaha.

Berdasarkan beberapa penelitian terdahulu, terdapat faktor-faktor yang dapat memotivasi mahasiswa berwirausaha diantaranya adalah keberhasilan diri, toleransi akan risiko, dan kebebasan dalam bekerja. Ketiga faktor ini menjadi penting untuk diteliti kembali karena dalam penelitian terdahulu, terbukti ketiga faktor ini signifikan mempengaruhi motivasi mahasiswa untuk berwirausaha. Dengan karakteristik wilayah Bangkalan yang berbeda dengan wilayah pada penelitian terdahulu, menarik untuk dilakukan penelitian untuk menjawab permasalahan tentang adakah pengaruh keberhasilan diri, toleransi akan risiko, dan kebebasan dalam bekerja terhadap motivasi berwirausaha pada mahasiswa.

Schumpeter mendefinisikan wirausaha sebagai orang yang mampu membaca peluang kemudian menciptakan organisasi untuk memanfaatkan peluang tersebut (Alma, 2009: 24). Mereka mampu menangkap peluang, menciptakan kegiatan usaha, dan memiliki keberanian dalam mengambil risiko dengan berpijak pada kemauan dan kemampuan sendiri. Lebih lanjut profil seorang wirausaha diwarnai oleh percaya diri, berorientasi tugas dan hasil, pengambil risiko, kepemimpinan, keorisinilan, dan berorientasi ke masa depan (Meredith, 2000: 5).

Seorang wirausaha tidak lepas juga dari motivasi. Motivasi berasal dari kata motif yang berarti suatu keadaan dalam pribadi orang yang mendorong individu untuk melaksanakan aktivitas tertentu guna mencapai suatu tujuan (Basrowi, 2011: 65). Teori motivasi pertama kali dikemukakan oleh Abraham Maslow yang popular dengan sebutan Teori Motivasi Hierarki Kebutuhan Maslow. Maslow berpendapat bahwa hierarki kebutuhan manusia dapat dipakai untuk melukiskan dan meramalkan motivasinya. Menurutnya, kebutuhan bertingkat sesuai dengan tingkatan pemuasannya, yaitu kebutuhan fisik, kebutuhan keamanan, kebutuhan sosial, kebutuhan harga diri, dan kebutuhan aktualisasi diri (Suryana, 2009: 54).

Tokoh motivasi yang lain adalah McClelland, yang menyatakan bahwa pada dasarnya motivasi seseorang ditentukan oleh tiga kebutuhan, yaitu kebutuhan akan kekuasaan, kebutuhan akan afiliasi, dan kebutuhan akan keberhasilan (Alma, 2009: 96). Teori selanjutnya adalah "Push" dan "Pull" Theory yang dikembangkan oleh Gilad dan Levine (1986). Menurut Push Theory, setiap individu didorong untuk menjadi wirausahawan oleh faktor- 
faktor eksternal yang bersifat negatif, seperti ketidakpuasan kerja, kesulitan mendapatkan pekerjaan (bekerja pada orang lain), gaji yang tidak memadai, atau jadwal kerja yang tidak fleksibel. Sebaliknya Pull Theory berargumentasi bahwa orang tertarik untuk menjadi wirausahawan karena hasrat akan kemandirian, kebebasan, aktualisasi diri, keberhasilan, kekayaan, atau hal lainnya yang cenderung bersifat positif.

Salah satu daya tarik berwirausaha adalah untuk mencapai keberhasilan diri. Menurut McClelland seseorang yang memiliki kebutuhan tinggi untuk berhasil akan melakukan sesuatu yang lebih efisien dibanding sebelumnya serta menunjukkan perilaku dengan standart excellent (Basrowi, 2011: 17). Ini menunjukkan pentingnya motif berprestasi. Selanjutnya hal senada dinyatakan oleh Meredith bahwa salah satu ciri wirausaha adalah berorientasi pada tugas dan hasil (Meredith, 2000: 5).

Keberhasilan wirausaha tidak lepas dari keberanian dan kemampuan dalam menghadapi risiko. Dalam hal ini umumnya wirausaha akan menghindari situasi risiko yang rendah karena tidak ada tantangan dan menjauhi situasi risiko yang tinggi karena ingin berhasil (Basrowi, 2011: 27). Sikap seorang wirausaha atas risiko ini erat kaitannya dengan kapabilitas yang tergantung pada sifat dinamis dan progresifnya (Sofyan, 2000). Risiko secara eksplisit dapat digunakan sebagai penentu pengambilan keputusan seseorang untuk menjadi wirausaha (Praag dan Cramer, 2001). Demikian pula menggunakan risiko yang telah diantisipasi sebagai alat untuk memprediksi keinginan seseorang untuk menjadi wirausaha, dinyatakan "semakin toleran seseorang dalam menyikapi suatu risiko semakin besar insentif orang tersebut untuk menjadi wirausaha" (Douglas dan Shepherd, 1999).

Seorang wirausaha juga senang kemandirian dan kebebasan dalam bekerja. Kebebasan dalam hal ini berarti bebas dari pengawasan dan aturan birokrasi organisasi (Basrowi, 2011: 25). Mengutamakan kebebasan dalam bekerja adalah salah satu karakteristik wirausahawan, dimana mereka sangat mementingkan kepuasan pribadi dalam bekerja, seperti dapat mengatur usaha secara fleksibel dan membentuk struktur organisasi sesuai dengan keinginan (Saiman, 2009: 49). Gambaran kelompok wirausaha yang sangat mengedepankan kebebasan dalam bekerja ini digambarkan dengan sangat baik dalam konsep cash flow quadrant oleh Kiyosaki, dimana para wirausaha berada pada kuadran "S" (memiliki pekerjaan/ pekerja lepas) (Sunarya, dkk, 2011: 23). Mereka adalah orangorang yang ingin menjadi bos bagi diri mereka sendiri. Mereka ingin melakukan apa yang mereka mau sehingga sering disebut "kelompok melakukan sendiri".

Beberapa temuan peneliti tentang motivasi berwirausaha diantaranya Lukiastuti (2009), yang menyatakan bahwa faktor dominan motivasi mahasiswa berwirausaha adalah faktor kesempatan, faktor kepuasan, dan faktor kebebasan. Koesworo, Sina, dan Nugeraheni (2007) menghasilkan bahwa perceived net desirability, tolerance of risk, perceived feasibility of self employment terbukti berkorelasi positif dengan motivasi kewirausahaan. Widhari dan Suarta (2012), keberhasilan diri, toleransi akan risiko, dan kebebasan melakukan pekerjaan memiliki pengaruh positif dan signifikan terhadap entrepreneurship, sekaligus memiliki pengaruh yang signifikan terhadap keinginan mahasiswa untuk menjadi wirausaha sebesar 40,3\%. Segal, Borgia, dan Schoenfeld (2005), membuktikan bahwa tolerance for risk, perceived feasibility, and perceived net desirability signifikan mempengaruhi motivasi kewirausahaan. Sedangkan penelitian Wang, Prieto, Hinrichs, dan Milling (2012) menghasilkan temuan bahwa faktor kebebasan dan toleransi akan risiko merupakan prediktor motivasi kewirausahaan yang terbaik untuk Mexico, USA, dan Cina. 
Berdasarkan kajian pustaka di atas, peneliti merumuskan hipotesis sebagai berikut:

1. Diduga keberhasilan diri, toleransi akan risiko dan kebebasan dalam bekerja secara bersama-sama berpengaruh signifikan terhadap motivasi berwirausaha.

2. Diduga keberhasilan diri berpengaruh signifikan terhadap motivasi berwirausaha.

3. Diduga toleransi akan risiko berpengaruh signifikan terhadap motivasi berwirausaha.

4. Diduga kebebasan dalam bekerja berpengaruh signifikan terhadap motivasi berwirausaha.

\section{METODE PENELITIAN}

Pendekatan dalam penelitian ini adalah pendekatan kuantitatif. Penelitian ini dirancang dengan menggunakan penelitian asosiatif. Variabel yang digunakan pada penelitian ini adalah yaitu motivasi berwirausaha (Y), serta keberhasilan diri (X1), toleransi akan risiko (X2) dan kebebasan dalam bekerja (X3).

Populasi dalam penelitian ini adalah mahasiswa Program Studi Pendidikan Ekonomi di STKIP PGRI Bangkalan yang sedang menempuh semester VII pada tahun akademik 2012-2013 yaitu sebanyak 120 orang mahasiswa. Seluruh anggota populasi diambil sebagai sampel. Data dikumpulkan melalui kuesioner, wawancara, dan dokumentasi. Kuesioner disusun berdasarkan variabel penelitian dan indikator penelitian dengan skala pengukuran instrument menggunakan skala likert. Tehnik analisis menggunakan analisis uji statistik yaitu uji F dan uji t. Uji F digunakan untuk menguji signifikansi variabel keberhasilan diri, toleransi resiko, dan kebebasan bekerja terhadap motivasi berwirausaha. Uji t digunakan untuk menguji signifikansi pengaruh keberhasilan diri terhadap motivasi berwirausaha, pengaruh toleransi resiko terhadap motivasi berwirausaha dan pengaruh kebebasan bekerja terhadap motivasi berwirausaha.

\section{HASIL PENELITIAN DAN PEMBAHASAN}

\section{Hasil Penelitian}

Uji asumsi klasik meliputi uji normalitas, multikolinieritas dan heteroskedastistas.

1. Uji Normalitas

Uji normalitas menggunakan Uji Kolmogorov Smirnov dengan bantuan SPSS 17.0 for Windows dihasilkan Asymp. Sig $>0,05$, dengan demikian asumsi normalitas data terpenuhi.

2. Uji Multikolinearitas

Uji normalitas, dilakukan dengan bantuan SPSS 17.0 for Windows ditunjukkan oleh tabel coefficient dengan mengamati kolom tolerance dan kolom VIF. Didapatkan nilai tolerance ketiga variabel $>0,1$ dan nilai VIF ketiga variabel $<10$. Dengan demikian tidak ada multikolinearitas antara variabel bebas dalam model regresi.

3. Uji Heteroskedastisitas

Uji heteroskedastisitas, menggunakan uji Rank Spearman dengan bantuan SPSS 17.0 for Windows. Didapatkan signifikansi untuk X1 $=0,858>0,05$, untuk X2 $=0,957>$ 0,05 , dan untuk X3 $=0,771>0,05$. Dengan demikian hasil uji Rank Spearman menunjukkan pada model tidak terjadi heteroskedastisitas.

Model regresi yang diperoleh berdasarkan hasil penelitian, dapat dituliskan dalam bentuk persamaan regresi sebagai berikut: $\mathrm{Y}=0,514 \mathrm{X} 1+0,239 \mathrm{X} 2+0,093 \mathrm{X} 3+$ ei. Dari 
persamaan tersebut, ketiga variabel bebas memiliki koefisien regresi dengan arah positif. Hal ini berarti bahwa semakin tinggi keberhasilan diri, toleransi akan risiko, dan kebebasan dalam bekerja akan meningkatkan motivasi kewirausahaan dalam diri mahasiswa. Hasil uji F berdasarkan uji ANOVA atau uji statistik F, model menunjukkan nilai F sebesar 44,648 dengan probabilitas sebesar 0,000 . Nilai $F$ hitung lebih besar dibandingkan nilai $F$ tabel $(2,68)$ dan nilai signifikansi tersebut lebih kecil dari 0,05 . Hal ini berarti bahwa motivasi berwirausaha dapat dijelaskan oleh variabel keberhasilan diri, toleransi akan risiko, dan kebebasan dalam bekerja secara bersama-sama atau dengan kata lain semua variabel bebas secara bersama-sama merupakan penjelas yang signifikan terhadap variabel terikat.

Koefisien korelasi sebesar 0,732 berarti hampir 53,6\% motivasi kewirausahaan dipengaruhi oleh keberhasilan diri, toleransi akan risiko, dan kebebasan dalam bekerja. Sedangkan 46,4\% dipengaruhi oleh variabel lain diantaranya proses pembelajaran, dan lingkungan.

Lebih lanjut uji parsial menunjukkan tidak semua variabel pengaruhnya signifikan. Uji parsial menunjukkan variabel keberhasilan diri memiliki nilai t hitung sebesar 5,806 dengan signifikansi 0,000 ; variabel toleransi akan risiko memiliki nilai t hitung sebesar 2,674 dengan signifikansi 0,009 dan variabel kebebasan dalam bekerja memiliki nilai t hitung 1,416 dengan signifikansi 0,160. Nilai t hitung dikonsultasikan dengan nilai $t$ tabel untuk taraf signifikansi 0,05 sebesar 1,664. Ternyata nilai thitung untuk variabel keberhasilan diri dan toleransi lebh besar dari t tabel, menunjukkan variabel keberhasilan diri pengaruhnya signifikan terhadap motivasi berwirausaha. Demikian halnya dengan toleransi akan resiko pengaruhnya signifikan terhadap motivasi berwirausaha. Lain halnya dengan variabel kebebasan dalam bekerja nilai t hitung lebih kecil dari nilai t tabel, menunjukkan pengaruh kebebasan dalam bekerja tidak signifikan terhadap motivasi berwirausaha.

Lebih lanjut koefisien korelasi variabel kebebasan diri dengan motivasi berwirausaha 0,703, korelasi toleransi akan resiko dengan motivasi berwirausaha sebesar 0,622 dan korelasi kebebasan dalam bekerja dengan motivasi berwirausaha sebesar 0,277. Berarti motivasi berwirausaha dipengaruhi oleh 49,4\% kebebasan diri dalam bekerja dan 38,6\% oleh toleransi akan resiko. Sedangkan pengaruh kebebasan dalam bekerja terhadap motivasi berwirausaha relatif kecil dan tidak bermakna.

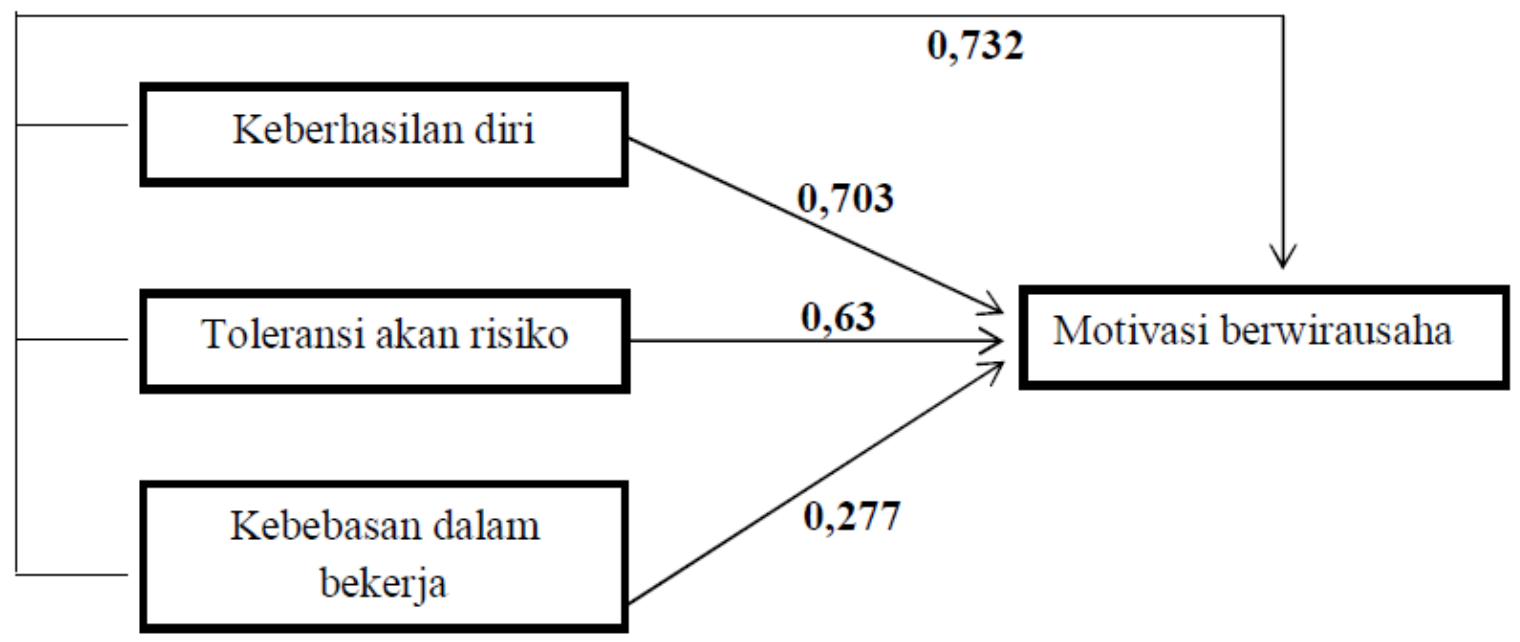

Sumber : : Data primer yang diolah, 2012 


\section{Pembahasan}

\section{Gambar 1.Hasil Uji Hipotesis}

1. Keberhasilan Diri, Toleransi Akan Resiko, dan Kebebasan Dalam Bekerja Terhadap Motivasi Berwirausaha

Hasil penelitian menunjukkan bahwa keberhasilan diri, toleransi akan risiko dan kebebasan dalam bekerja secara bersama-sama berpengaruh signifikan dan positif terhadap motivasi berwirausaha pada mahasiswa. Implikasi dari temuan tersebut adalah, semakin tinggi keberhasilan diri, toleransi akan risiko dan kebebasan dalam bekerja maka semakin tinggi motivasi berwirausaha. Sebaliknya semakin rendah keberhasilan diri, toleransi akan risiko dan kebebasan dalam bekerja maka semakin rendah motivasi berwirausaha. Hal ini sesuai dengan penelitian-penelitian sebelumnya seperti yang telah dibuktikan oleh Widhari dan Suarta (2012).

Tingginya semangat kewirausahaan dalam jiwa mahasiswa sebenarnya merupakan harapan cerah bagi lembaga untuk membantu program pemerintah dalam mencetak wirausaha-wirausaha muda mandiri sehingga jumlah wirausaha di Indonesia akan mencapai standar yaitu sebanyak 2 persen dari total penduduk sehingga dapat meningkatkan kualitas perekonomian bangsa Indonesia, kedepan Indonesia akan menjadi bangsa yang kuat karena ditopang oleh wirausaha-wirausaha yang kuat dan handal. Salah satu upaya yang bisa dilakukan adalah dengan memupuk jiwa wirausaha yang sudah ada dengan cara diantaranya meningkatkan kualitas pembelajaran kewirausahaan dari segi dosen yang berpengalaman menekuni wirausaha sehingga mahasiswa tidak hanya mendengarkan teori namun sebuah pengalaman nyata sehingga lebih tercerap dalam jiwa yang akan memupuk keberanian untuk memulai. Selain itu materi kewirausahaan dikemas semenarik mungkin sehingga tidak monoton dan membosankan karena sangat teoritis. Kemudian juga ditunjang dengan menambah frekuensi seminar dan pelatihan kewirausahaan yang dipadankan dengan potensi keunggulan wilayah. Hal penting lainnya yang dapat dilakukan oleh lembaga yaitu menciptakan inkubator kewirausahaan dengan memberikan modal kewirausahaan bagi mahasiswa wirausaha sekaligus pembimbingan intensif dan pendampingan wirausaha, sehingga embrio kewirausahaan ini siap hidup dan bisa dikembangkan setelah mahasiswa lulus.

Beberapa faktor yang mendukung tingginya motivasi berwirausaha mahasiswa STKIP PGRI Bangkalan diantaranya semangat berwirausaha, fokus terhadap tujuan berwirausaha, optimis dalam menjalankan usaha, tekun dan ulet dalam berwirausaha, kompeten dalam bidang usaha, memiliki kolektifitas berwirausaha, memiliki tanggung jawab terhadap usaha, menyukai tantangan usaha, sabar dan kontrol diri dalam berwirausaha, tidak suka di atur dalam bekerja, suka mengambil inisiatif dalam berwirausaha, bebas dari supervisi dalam pekerjaan, bebas jam kerja, dan bebas dalam menentukan pendapatan usaha.

\section{Keberhasilan diri.}

Keberhasilan diri berpengaruh signifikan dan positif terhadap motivasi berwirausaha pada mahasiswa. Keberhasilan diri yang lebih besar yang diperoleh mahasiswa dapat meningkatkan jiwa kewirausahaan dalam diri mahasiswa. Hasil pengujian hipotesis ini mendukung teori yang disampaikan oleh McClelland, Maslow, serta Gilad dan Levine. Demikian juga sesuai dengan hasil penelitian terdahulu yang dilakukan Widhari dan Su$\operatorname{arta}(2012)$. 
Menurut McClelland, seseorang berwirausaha didasari oleh kebutuhan akan keberhasilan/ prestasi ("nAch) dalam rangka mencapai suatu keberhasilan melalui unjuk kerja yang terbaik, tingkah lakunya diarahkan terhadap tercapainya standart of excellent, melakukan sesuatu yang lebih baik dan efisien dibanding sebelumnya. Temuan di lapangan telah membuktikan hal ini, dimana mayoritas responden memanfaatkan waktu luang dengan aktif di organisasi, mengikuti seminar-seminar kewirausahaan, bahkan 38 persen responden sudah menekuni wirausaha, sebagian lagi telah berprofesi sebagai Guru. Kendati demikian, prestasi akademik responden tergolong baik, dengan rata-rata IPK mencapai 3,32. Menurut Maslow, individu akan termotivasi untuk memenuhi kebutuhan yang paling dominan bagi mereka pada waktu tertentu, sehingga seseorang menekuni wirausaha untuk memenuhi sejumlah hirarki kebutuhan tersebut, dimulai dari kebutuhan yang paling dasar (kebutuhan fisik) hingga kebutuhan tertinggi, yaitu kebutuhan untuk mengaktualisasikan diri. Pull Theory dari Gilad dan Levine menyatakan bahwa orang tertarik untuk menjadi wirausahawan karena adanya hasrat akan sesuatu yang bersifat positif diantaranya ialah untuk mencapai keberhasilan.

\section{Toleransi akan resiko.}

Toleransi akan risiko berpengaruh signifikan dan positif terhadap motivasi berwirausaha pada mahasiswa. Toleransi yang lebih besar terhadap risiko akan memberikan jiwa entrepreneur yang lebih besar dalam diri mahasiswa. Hasil penelitian ini mendukung pendapat Douglas dan Shepherd, Praag dan Cramer, Rye, serta Meredith. Hasil penelitian ini juga sesuai dengan hasil penelitian terdahulu yang dilakukan oleh Widhari dan Suarta (2012), dan Koesworo dkk (2006). Juga sependapat dengan penelitian Wang, Yong and Poutziouris (2010) namun dalam konteks yang berbeda, dimana dapat dibuktikan bahwa intensitas pengambilan risiko seseorang berkorelasi dengan kinerja bisnis. Selain itu sejalan dengan hasil penelitian yang telah dilakukan Wang, Prieto, Hinrichs, dan Milling (2012), mereka membuktikan bahwa tingkat keberanian pengambilan risiko merupakan salah satu prediktor terbaik untuk memprediksi motivasi berwirausaha di tiga negara, yaitu China, Mexico, dan USA. Bahwa toleransi akan risiko terbukti signifikan mempengaruhi motivasi berwirausaha juga sesuai dengan hasil penelitian terhadap 114 mahasiswa Florida Gulf Coast University yang telah dilakukan Segal, Borgia, dan Schoenfeld (2005).

Menurut Douglas dan Shepherd (1999), semakin toleran seseorang dalam menyikapi suatu risiko maka semakin besar insentif untuk menekuni wirausaha. Menurut Praag dan Cramer (2001) risiko berperan dalam pengambilan keputusan seseorang untuk berwirausaha. Rye juga menyatakan bahwa salah satu kualitas profil wirausaha agar berhasil adalah keberanian dalam mengambil risiko. Kemudian menurut Meredith, wirausaha akan menghindari situasi risiko yang rendah karena tidak ada tantangan dan menjauhi situasi risiko yang tinggi karena ingin berhasil.

Temuan di lapangan yang menunjukkan sikap responden terhadap risiko diantarannya kesukaan responden terhadap tantangan tergolong tinggi, ditunjukkan oleh aktivitas mayoritas responden mengikuti berbagai jenis perlombaan intern maupun ekstern kampus. Responden juga memiliki antusiasme yang tinggi dalam menyambut peluang, diantaranya peluang untuk mengikuti berbagai seminar dan pelatihan. Namun sayangnya responden yang telah menekuni wirausaha mengalami kegagalan karena kurangnya mental dan keberanian menanggung risiko, dan jumlahnya mencapai $62 \%$. Perlu upaya untuk membangun mental keberanian terhadap risiko sehingga lebih motivasi mahasiswa meng- 
hidupkan kembali usahanya.

4. Kebebasan dalam bekerja terhadap motivasi berwirausaha

Kebebasan dalam bekerja tidak berpengaruh signifikan terhadap motivasi berwirausaha pada mahasiswa. Temuan ini tidak mendukung pendapat Rye bahwa mengutamakan kebebasan dalam bekerja adalah karakteristik wirausahawan dimana mereka mementingkan kepuasan pribadi dalam bekerja seperti dapat mengatur usaha secara fleksibel sesuai dengan keinginan. Demikian juga tidak mendukung pendapat Kiyosaki bahwa wirausaha adalah orang-orang yang ingin menjadi bos bagi mereka sendiri, sangat mementingkan kemandirian dalam bekerja dan tidak menyukai pengawasan.

Hasil pengujian hipotesis ini bertentangan dengan hasil penelitian sebelumnya yang dilakukan oleh Widhari dan Suarta (2012), keduanya membuktikan bahwa kebebasan dalam bekerja berpengaruh signifikan secara parsial terhadap motivasi berwirausaha. Hasil penelitian ini juga bertolak belakang dengan temuan penelitian di Rusia, bahwa alasan pemuda Rusia untuk berwirausaha $80 \%$ dikarenakan menginginkan kebebasan, otonomi, kemerdekaan atau menjadi bos. Juga tidak mendukung hasil penelitian Dawson dan Henley (2012) di bahwa faktor kebebasan adalah motivasi yang paling umum yang menyebabkan seseorang memutuskan untuk menjadi seorang wirausaha. Sikap responden terhadap kebebasan dalam bekerja pada taraf cukup tertarik. Hal ini karena umumnya responden yang diteliti adalah mahasiswa Fakultas Pendidikan dan mata kuliah Kewirausahaan hanya diberikan sebanyak 2 SKS dalam satu semester sehingga pembelajaran Kewirausahaan belum optimal.

\section{KESIMPULAN}

Dari pembahasan yang telah diuraikan, maka dapat ditarik simpulan sebagai berikut:

1. Keberhasilan diri, toleransi akan risiko dan kebebasan dalam bekerja secara bersamasama memiliki pengaruh yang signifikan dan positif terhadap motivasi berwirausaha pada mahasiswa.

2. Keberhasilan diri memiliki pengaruh signifikan dan positif terhadap motivasi berwirausaha pada mahasiswa. Keberhasilan diri yang lebih besar yang diperoleh mahasiswa dapat meningkatkan jiwa wirausaha dalam diri mahasiswa.

3. Toleransi akan risiko memiliki pengaruh signifikandanpositif terhadap motivasi berwirausaha pada mahasiswa. Toleransi yang lebih besar terhadap risiko akan memberikan jiwa wirausaha yang lebih besar dalam diri mahasiswa.

4. Kebebasan dalam bekerja tidak berpengaruh signifikan terhadap motivasi berwirausaha pada mahasiswa. Semakin tinggi kebebasan bekerja tidak diikuti oleh semakin tingginya motivasi berwirausaha.

Saran-saran yang dapat diberikan sebagai tindak lanjut dari hasil penelitian adalah sebagai berikut:

1. Lembaga perlu mengupayakan peningkatan kompetensi mahasiswa, hardskill maupun softskill sebagai bekal agar mahasiswa unggul dalam persaingan dunia kerja, memperbanyak kegiatan pelatihan-pelatihan kewirausahaan bagi mahasiswa yang lebih berorientasi pada praktik yang mendorong potensi yang dimiliki daerah.

2. Perlu ditingkatkan toleransi akan resiko melalui berbagai pembelajaran diri agar menambah kepekaan dalam membaca peluang.

3. Diperlukan peningkatan pembelajaran untuk membentuk mental mahasiswa melalui 
kesantunan dan kepatutan figur seorang guru.

4. Penelitian ini dapat dilanjutkan untuk menemukan faktor lain yang memotivasi mahasiswa untuk berwirausaha.

\section{DAFTAR RUJUKAN}

Alma, Buchari. 2009. Kewirausahaan. Bandung: Alfabeta.

Basrowi. 2011. Kewirausahaan untuk Perguruan Tinggi. Bogor: Ghalia Indonesia.

Dawson, Chrishtopher and Henley, Andrew. 2012. “"Push" Versus “Pull” Entrepreneurship: an Ambigous Distinction?".International Journal of Entrepreneurial Behavour\&Research. Vol 18 Iss: 6, pp. 697-719.

Doughlas, E.J. dan Sheperd, D.A. 1999.“Entrepreneurship as a Utility Maximizing Response".Journal of Business Venturing. Vol 15 No 3, pp. 231-251.

Gilad, B. and Levine, P. 1986. A Behavioural Model of Entrepreneurial Supply. Journal of Small Business Management, pp. 45-53.

Kemenkop dan UKM. www.bisnis.com, diakses 7 Mei 2012.

Koesworo, Yulius, Siprianus S. Sina, Diana Nugeraheni. 2007. "Motivasi Berwirausaha di Kalangan Mahasiswa: Aplikasi Theory of Planned Behavior". Jurnal Ekuitas Vol 11 No. 2 Maret 2007. Hal: 269-291.

Lukiastuti, Fitri. 2009. “Analisis Faktor-faktor yang Mempengaruhi Motivasi Mahasiswa STIE Bank BPD Jateng untuk Menjadi Wirausaha”. Jurnal Prestasi Vol 5 No 1 Juni 2009. Hal: 14-34.

Meredith, Geoffrey G. 2000. Kewirausahaan: Teori dan Praktek. Jakarta: PT Pustaka Binaman Pressindo.

Praag, C.M. dan Cramer, J.S. 2001. "The Roots of Entrepreneurship and Labor Demand: Individual Ability and Low Risk". Economica. Vol 68 No 269, pp. 45-62.

Saiman, Leonardus. 2009. Kewirausahaan Teori, Praktik, dan Kasus-kasus. Jakarta: Salemba Empat.

Sunarya, Abas, Sudaryono dan Asep Saefullah. 2011. Kewirausahaan. Yogyakarta: Andi.

Suryana. 2009. Kewirausahaan Pedoman Praktis: Kiat dan Proses menuju Sukses. Jakarta: Salemba Empat.

Segal, Gerry, Borgia, Dan and Schoenfeld. 2005. "The Motivation to Become an Entrepreneur". International Journal of Entrepreneurial Behavour\&Research. Vol 11 Iss: 1, pp. 42-57.

Sofyan, Iban. 2000. Manajemen Risiko. Jurusan MGT. FE Unila.

Wang, Lei, Prieto, Leonel, Hinrichs and Milling. 2012. "A Cross-Cultural Study of Motivation for Self-Employment: Comparing China, Mexico, and the USA". International Journal of Entrepreneurial Behavour\&Research. Vol 18 Iss: 6, pp. 649-672.

Wang, Yong, and Poutziouris, Panikkos. 2010. "Entrepreneurial Risk Taking: Empirical Evidence from UK Family Firms". International Journal of Entrepreneurial Behaviour\&Research. Vol 16 Iss: 5, pp. 370-388.

Widhari, Cokorda Istri Sri, I Ketut Suarta.2012. “Analisis Faktor-faktor yang Memotivasi Mahasiswa Berkeinginan Menjadi Wirausaha”.Jurnal Bisnis dan Kewirausahaan Vol 8 No 1 Maret 2012. Hal 54-63. 